\title{
Psycho and The Orchestration of Anxiety
}

Stephen Deutsch, Bournemouth University

\section{Abstract}

Since its release in 1960, Alfred Hitchcock's Psycho has entered the consciousness of our culture as have few other films. Its striking imagery, combined with its universally recognised score, has prompted a wealth of scholarly output. New understanding in the areas of emotion and cognition now affords us the opportunity to re-examine this film from a less familiar vantage point. This article places Psycho within the context of American TV drama of the 1950s and explores the effect of Bernard Herrmann's music on the emotional responses of the viewer, as well as the possible consequences of this effect upon the literal reading of the film.

Keywords

TV Drama, Hitchcock, Emotional signifiers, Psycho, Herrmann, Mood and Cognition

\section{Introduction}

In the 50 years since its first release, Psycho (1960) has been much discussed and written about; it continues to fascinate. Much of the writing on the subject has focussed on filmic issues, especially those concerning the notion of authorship, psychology, genre, and gender. Books and articles which address the aural aspects of the film tend to centre on the more musicologically focussed issues; few discuss the sound world of the entire film (Elisabeth Weis, in her Silent Scream [1982] being a laudable exception to this generalisation). The focus on music in this film (and in this article) is hardly surprising, however, as Psycho's production process closely resembled the practice of late 50's television drama rather than of cinema, and as a result very few non-musical sonic statements were part of the film's acoustic landscape, despite Hitchcock's normal proclivity to use sound as a structural device ${ }^{1}$.

What is undeniable, is that for a number of reasons extremely well rehearsed elsewhere, audiences found the film shocking and disturbing. Hitchcock had played the audience "like an organ" (Truffaut, 417).

There were many factors which contributed to our shock, not least of which were expectations we brought to the cinema before the first frame was screened. Some of these expectations were informed by television, especially for American audiences.

\footnotetext{
${ }^{1}$ There are of course conspicuous and effective instances where non-musical sound carries information, especially in the use of disembodied voices. See below, and Weis, 1982, p134.
} 


\section{American cinema and tv drama in the 50s}

Although Britain and Germany produced limited scheduled television broadcasts before the Second World War, it was in the USA that television took first post-war root. ${ }^{2}$ Early television was studio based, and drama was a staple in the output of the networks. Regular one-off dramas appeared on television as early as 1947, and by the mid 50s, many prime-time hours were devoted to single dramas, usually performed live to camera (with a few filmed inserts to help scene changes). ${ }^{3}$ The list of these programmes includes long running series such as Armstrong Circle Theatre, (1950-63), The Unites States Steel Hour (1949-53), Kraft Television Theatre (1947-58), and Playhouse 90 $(1956-60)^{4}$. There were several others.

Television drama, given its stage roots, was vococentric, and in many ways its sound world mimicked that which might be heard in theatre. Sound effects were used to depict events impossible to stage, or to heighten gestures (gunshots, weather, etc). Music was used as emotional signification, but rarely under dialogue. Also, the technology of the television receiver was such that (at least until the later 50s) only a narrow range of frequencies and amplitudes could be accommodated. With dialogue in the foreground, there was room for little else.

\section{Hitchcock}

"Psycho" was an experiment in this sense: could I make a feature film under the same conditions as a television show?" (Alfred Hitchcock, in Truffaut, 436)

Hitchcock was probably the first director whose own persona transcended the movies he made, at least in popular consciousness in the United States between 1955 and 1965 (which was also the period during which he made some of his most accomplished and successful films). From 1955 to 1965, Hitchcock regularly appeared on television, hosting his own show, Alfred Hitchcock Presents (later The Alfred Hitchcock Hour). ${ }^{5}$

\footnotetext{
2 This is hardly surprising, given the economic devastation suffered in most European countries by 1945. It should also be noted, en passant, that in 1939 very few homes were able to receive television broadcasts (or could afford the televisions); Television broadcasting the USA didn't really get going until after the war; the real growth occurred in the decade starting in 1948. In Nazi Germany, television broadcasting was designed for communal rather than private viewing. Television didn't really establish itself in either the BRD or GDR until the mid-fifties.

${ }^{3}$ It is fascinating to note that if a drama received rave notices, it was repeated live a few days later.

${ }^{4}$ Playhouse 90 in particular was a major contributor to the careers of those who would later become important in film. They include Rod Serling, Abbey Mann and John Frankenheimer (among many others). Several of the plays premiered in air were later remade as films, such as Days of Wine and Rose" (Edwards 1962), Requiem for a Heavyweight (Nelson, 1962), and Judgement at Nuremberg (Kramer, 1961).

5 The programme was aired at peak time on Sunday (9.30 p.m, 8.30 Central Time Zone). In the ten years of its initial run, over 253 episodes, Hitchcock helped the careers of several directors, including Arthur Hiller (who directed 17 episodes), Robert Altman (2 episodes) and Stuart Rosenberg (four episodes) and various writers, including Roald Dahl, Ray Bradbury and Robert Bloch.
} 
A good example of the sonic world of television drama can be seen in an episode of that series entitled "Lamb to the Slaughter" and broadcast on 13 April 1958. The script was by Roald Dahl, and Hitchcock himself directed. The Director of Photography was John L Russell, who would have the same role in Psycho. The music is uncredited. In many ways, this 25 minute film bears resemblance to Psycho; the studio setup is unpretentious, the sound is cleanly recorded and audible, and the acting subtle (Barbara Bel Geddes is the main character). There are very few sounds which were not provided by the actors' movements (a police car approaches of camera, its lights making a path on the window). ${ }^{6}$

Alfred Hitchcock Presents began and ended with a short piece to camera in which Hitchcock made (often facetious) comments about the show in question ${ }^{7}$. He directed very few of these programmes himself, yet his 'brand' attached to them ${ }^{8}$. His eccentric, intrinsically English, droll delivery was much enjoyed, and his penchant of comedysuspense as a sub-genre 9 inclined audiences to expect thrills tinged with humour. The trailer for Psycho, shot on the motel set on the day principal shooting ended, capitalised on the affection audiences felt for this persona. He takes the viewer on a tour of the set, almost (but not quite) giving away the plot, seducing the viewer into the expectation that they will see a film very similar to other Hitchcock films. This expectation was to be shattered.

As were others. The biggest (indeed the only) star in the film was Janet Leigh. By 1960 she was almost an "A list" actor, and a screen icon. In 1960, such icons were not killed, especially not within the first half of the film. Her character's death came therefore as a double shock, from both sides of the screen.

As we have come to learn from many sources, Psycho was a difficult and problematic project. Hitchcock therefore decided to invest his own money in the film, and as a result endeavoured to produce it as inexpensively as possible (Rebello, 1990). He used crews from his TV series, minimised exterior locations (as compared to Vertigo and North By Northwest) and cast the film similarly, with A-minus or B list actors, some of which had been used on the television series ${ }^{10}$. Bernard Herrmann was equally well versed in the television aesthetic (and more importantly the production/post-production

\footnotetext{
${ }^{6}$ This episode is available for viewing on YouTube:http://www.youtube.com/watch?v=BmpY9cpe6g8 I have been reminded that in the previous year, Hitchcock directed an episode of the show entitled "One More Mile to Go" which seems a rehearsal for the Psycho scene in which the policeman interrogates Marion through the window of her car.

${ }^{7}$ Sometimes he was required to film two versions of the opening sequence, especially when he poked fun at the sponsors, about which the British affiliates were not as amused as the Americans.

${ }^{8}$ Hitchcock directed 17 of the 268 episodes which were broadcast between 1955 and 1962.

${ }^{9}$ He believed Psycho to be in such a mold (Truffaut 1978).

${ }^{10}$ Martin Balsam and John McIntire had been featured in that series; all of the principal cast, save John Gavin and Janet Leigh, had extensive experience in TV drama.
} 
restrictions of broadcasting). ${ }^{11}$ The decision to shoot the film in black and white may have arisen from a televisual mind-set. However, Hitchcock asserted that the choice of monochrome was prompted by the influence of Clouzot's Diabolique (1955), a film which Hitchcock admired so much that he had his scriptwriter on Psycho, Joe Stefano (and other members of the crew) see it (Skerry, 227).

Hitchcock's use of sound had almost always focussed on effect rather than in producing a faux reality. Even in his more expensive productions, no real attempt was made to provide us with a "realistic" sound world, full of lavish atmospheres, extraneous foley and other effects. It can be argued that the process of film-making, technically and historically, in the first three decades of sound was not biased toward naturalism as we understand that term (or hyper-reality, as some modern big-budget films might suggest). In any event, our modern notion of "naturalism" would not have been at the forefront of the priorities of mid-century filmmakers. At this time, the process of recording sound on set (or after 1950 also on location) was completely centered on intelligibility of dialogue $^{12}$. Music was used primarily as emotional signaling (sometimes in a primitive way, with "stings" --sudden harsh chords-- marking key moments) ${ }^{13}$. Generally, in dialogue scenes, music was either missing, or highly attenuated.

Hitchcock always used sound meticulously, not to approximate a notion of naturalism, but to heighten the emotional impact of his films on his audience. As Marion begins her journey to California we can hear other characters' voices.

...in Psycho an interior monologue presents conscious thoughts while unconscious motivations are suggested through other means. As Marion drives away with the stolen money, she imagines the reactions of her employer and sister when they discover the crime... The voices are a reasonable representation of what might occur; Marion's thoughts are quite rational. But her behavior ... is irrational. Her paranoia is conveyed less by her thoughts than by the shots of rain on the windshield through which we can see successively closer and more intense shots of her eyes. (Weis, 1982, 41-42)

Marion's emotional and irrational state is also signaled through the music.

\section{On Emotion and Moods}

Recent research suggests that being in an emotional state changes not only the way we feel, but also the way we think. (Thayer, 1996) The chemical and the associative electrical responses in our brain create thought pathways (for lack of a better term) from which it is very difficult to deviate. In the emotional state of worry, which is fear and

\footnotetext{
${ }^{11}$ However, the choice of using a string orchestra was an aesthetic choice rather than an budgetary constraint.

${ }^{12}$ As it is today, as many would argue.

${ }^{13}$ Deftly parodied by Mel Brooks in High Anxiety, (1977)
} 
anxiety in various combinations, any conscious imposition of logical processes seems always short lived. And the worry blinds us to other things, things we might need to understand in order to find a solution to the problem which is at the centre of the anxiety.

Mood is related to emotion in that is shares some of the same suppressive cognitive elements, but is more of a background state, colouring more subtly how we think. Mood often can be the longer lasting residue left by an emotional state.

Three types of evidence suggest that the substrates of cognition are shared with, or open to extensive influence by, the substrates of mood. The first comes from functional neuroimaging. The other two come from behavioral studies of cognition. These include studies of the effects of depression on cognition, already mentioned, and of the effects of laboratory-induced moods on the cognitive processes of normal healthy participants. (Farah, Chepenik and Cornew, 2007)

Studies have also shown that mood can be affected by music and by film (Thayer 1989; 23-24). If one accepts the notion that music's role in film is primarily of emotional signification (Deutsch 2008), and combine that understanding with how (musically signified) emotion affects cognition, a case can be made for the hypothesis that in Psycho, music guides the audience's thought patterns in parallel with their feelings.

"Music that was expected to induce sadness produced large changes in heart rate, blood pressure, skin conductance and temperature; 'fearful' music produced large changes in pulse rate and amplitude..."(Mithen, 95)

It is not only the cognitive areas of the brain which are affected by music, but the precognitive areas as well. As we chart the brain's historical development, we can see that music, specifically rhythm, has an effect on the cerebellum. It "...taps into primitive brain structures involved with motivation, reward and emotion". Rhythm in particular excites this part of the brain, where "...computational systems in the brain synchronise neural oscillators with the pulse of the music, and begin to predict when the next strong beat will occur..." (Levitin 191). A regular rhythm tends to produce the comfort of habituation ${ }^{14}$. As Daniel Levitin (2006: 186) notes, "Habituation is an important and necessary process to separate the threatening from the non-threatening". A regular rhythm is generally non-threatening; ${ }^{15}$ an irregular rhythm might alert us to danger, but also prevent flight (Levitin, 2006: 174).

\footnotetext{
${ }^{14}$ It must also be stressed that a regular rhythm can provoke tension, but usually the tension is created by other factors, such as increased volume, dissonance, or timbral friction. Regular rhythms as tension producing devices can be found in Shostakovitch's $7^{\text {th }}$ Symphony (1941), and in Holst's "Mars" from The Planets (1916) as well as in many other works. The issue of habituation, however, implies that such patterns remain fixed, with little discernable change.

${ }^{15}$ This is addressed below in the discussion of the ostinato patterns in the 'money' music.
} 
It is likely a common occurrence, especially as we get older, that sleep is interrupted through worry. For me, the prime-time slot for worry seems to be about $4 \mathrm{am}$. It's an interesting and frustrating process. A thought enters the mind, one which troubles us; it loops around and connects to subsidiary concerns. They in turn orbit our disturbed sleep. In this semi-conscious state we attempt either to "put it out of our mind", or to "think it through". Neither strategy proves effective. The thoughts return; oblivious to our desire to impose logic. They continue to circuit our minds, until either we wake, or fall back into restless sleep.

Worry $^{16}$

\author{
Main Entry: ${ }^{1}$ wor·ry \\ Pronunciation: 〈'wər-ēe, 'wə-rē \ \\ Function: verb \\ Inflected Form(s): wor·ried; wor·ry·ing
}

Etymology: Middle English worien, from Old English wyrgan; akin to Old High German wurgen to strangle, Lithuanian veržti to constrict

Date: before 12th century

transitive verb 1 dialect British : choke, strangle $\mathbf{2}$ a : to harass by tearing, biting, or snapping especially at the throat $\mathbf{b}:$ to shake or pull at with the teeth $<$ a terrier worrying a rat $>\mathbf{c}$ : to touch or disturb something repeatedly $\mathbf{d}$ : to change the position of or adjust by repeated pushing or hauling $\mathbf{3} \mathbf{a}$ : to assail with rough or aggressive attack or treatment : torment $\mathbf{b}:$ to subject to persistent or nagging attention or effort4 : to afflict with mental distress or agitation : make anxious intransitive verb 1 dialect British : strangle, choke 2 : to move, proceed, or progress by unceasing or difficult effort : struggle $3:$ to feel or experience concern or anxiety : fret 'worrying about his health'

In Psycho, our emotional state and our identification with the worries of Marion Crane blind us to the potent signs of the danger she is in once she arrives at the motel, if not before (waking in her car).

For example, birds are a constant and mostly threatening theme in the film, not often noticed by the audience. ${ }^{17}$ After the titles, the first word we read is "Phoenix", which refers to a city and avian entity simultaneously. Marion's surname is "Crane". The patrolman perches over Marion as she wakes, his eyes (formed by opaque sunglass lenses) are large and black, and the camera tilt produces a beak-like nose and chin. There are, of course, stuffed birds in Norman's parlour, and pictures of birds on the walls of Marion's motel bedroom. Camera tilts in the parlour accentuate Norman's avian appearance, especially when he leans forward menacingly, after Marion mentions

\footnotetext{
${ }^{16}$ Merriam-Webster Dictionary Online, Accessed 16/01/10.

${ }^{17}$ As many readers will know, so interested was Hitchcock in the power of avian iconography that he made them the centre of his next film, appropriately entitled The Birds (1963).
} 
the possibility of placing his mother in a "home". Most of the birds we see, or to which allusion is made, are raptors. ${ }^{18}$

\section{Music and its role in the film}

"When I first heard it, I realized what he's done. He's taken everybody's guts and used them for music." Joseph Stefano, scriptwriter of Psycho, original and remake (Sullivan, 243)

Bernard Herrmann, Hitchcock's collaborator from 1955 (The Trouble With Harry) to 1964 (Marnie) ${ }^{19}$ was in the first generation of a new type of film composer, a type which abandoned the "operatic" model of film scoring, replacing it with a more integrated style, which developed later into a style which can be called "convergent." (Deutsch, 2009)

Herrmann's music, particularly in this film, is composed using cellular elements (small phrases, often memorable, which are susceptible to being placed in different musical contexts), similar to a technique often employed by Stravinsky, especially evident in Petrushka (1911). Herrmann's cells often present themselves as ostinati (from "obstinate"; repetitive phrases which "loop" over time). Such small motivic phrases are the main material for the score ${ }^{20}$, presented in a harmonic texture which owes much to the polytonal world of Charles Ives (1874-1954), whom Herrmann admired and befriended. ${ }^{21}$ The benefit of composing with cellular material is that phrases can be placed in different combinations in the score, and be stretched to accommodate editing without losing musical integrity. The use of polytonal gestures allows cells of differing tonalities to co-exist in the same acoustic space. It also helps a composer to create subtle shifts from consonance to dissonance.

Much has been written about the choice of string orchestra for the film, and need not detain us here, save the issue of timbral variation. The nature of the close mic recording (multi-source mono recording) allows for very subtle timbral textures to emerge, especially in the viola lines. Such changes occur often when a change in mood is to be signaled as in the scene when Marion decides to steal the money (discussed in more depth below).

\footnotetext{
${ }^{18}$ There are also potent aqueous motifs: the rain, which propels Marion to her destiny; the shower, which is the scene of her end; and the swamp, which disposes of her.

${ }^{19}$ One might also mention the 13 scores Herrmann composed for the Alfred Hitchcock Hour, from 1963-65, none of which were directed by Hitchcock. Also noteworthy is the discarded score to Torn Curtain (1966), about which much has been written elsewhere. He also composed the music for the first series of The Twilight Zone (1959). But his music was replaced by the now iconic score of Marius Constant, which was more dissonant and contained a powerful "hook".

${ }^{20}$ Roy Prendergast (1977) offers notational examples of some of the elements of this score.

${ }^{21}$ Polytonality is the process of the simultaneous combination of different key centres, much as if one hand is playing a tune in $\mathrm{C}$ and the other the accompaniment in A (bitonality), and a trumpet adds to the sound in the key of $\mathrm{Db}$ (polytonality). Its capacity for variation and proclivity towards dissonance was attractive to many of the composers Herrmann admired.
} 
The audience's experience of the film is immediately led by the music. The famous opening cell is followed by others, juxtaposed in unpredictable patterns. ${ }^{22}$ Each cell is rather short, and may be combined with others, creating both familiarity and discontinuity. The style of the music, and the timbres asked of the string orchestra, is harsh and abrasive, in keeping with the disjointed graphics of the titles, each card being cut into pieces as we watch. This opening music appears later on several occasions, especially when Marion is driving, in flight from her life, which she has ripped apart from the relative comfort of Phoenix.

For the film to work, the audience needs to identify strongly with the MacGuffin, ${ }^{23}$ Marion Crane. After the fractured credits and its similarly fractious music, we enter her world as voyeurs. The music which accompanies this first sequence is in great contrast to the opening. It is now played legato, using more conventional harmonies. During the discussions between the two lovers, the music takes a more gently melodic turn (fairly uncommon in Herrmann's technique) with harmonies redolent of romance, and echoes of (even) Puccini. They are in love, we feel, and our feelings about them prompt us to the thought that he is a fool to abandon her.

The next scene with a music cue, entitled "money" in Herrmann's score, is crucial in order for us to engage in Marion's world and to become involved in her anxiety. Marion is faced with a dilemma about whether to take the money to the bank or to steal it. We see her (as voyeurs again) clad in black bra and slip, the colour of the material contrasting with the more innocent white undergarments she wore in the hotel scene. The room is drab (we are allowed a glimpse of her shower through the open bathroom door), and there are a few homely pictures on the wall. She paces and packs, the suitcase open, the $\$ 40,000$ bulging in an envelope which has been placed on the bed. The camera returns to the money regularly. There are no diegetic sounds beyond studio atmosphere and the naturalistic subtle noises of her movements. The music begins when the camera first comes to rest on the cash.

The music here is quite straightforward; two cells, one static (sustained high and low notes) the other in constant movement ${ }^{24}$. This middle voice, played by the violas, seems at first to be an ostinato, which should provoke comfortable habituation. Part of the process of habituation is that the brain filters sounds which do not change ${ }^{25}$; but this is an eccentric ostinato, with notes unexpectedly absent, breaking the flow, and creating unease. Like worry, this music can't be put away. After shutting the suitcase, Marion again looks at the money, and the timbre of the ostinato changes. The middle voice

\footnotetext{
${ }^{22}$ Musical Examples can be found in Appendix 1.

${ }^{23}$ Hitchcock popularised the use of this term. Essentially it can serve as an object, or event or plot detail which catches the viewer's attention and drive the story. It is sometimes abandoned once the audience's attention is rooted on the narrative.

${ }^{24}$ The notation of this material can be found in Appendix 1.

${ }^{25}$ I spent my childhood in Brooklyn with a bedroom over which the BMT subway line rumbled 24 hours per day, but only noticed it when there was snow and the sound was different. By the way, in Saturday Night Fever, (Badham, 1977), John Travolta buys a piece of pizza from the pizzeria below my bedroom window. Thought you should know.
} 
becomes louder, more of the viola's naturally attenuated higher partials can be heard, and Marion has decided. The close-mic recording of the music allowed for these subtle details to emerge ${ }^{26}$. Herrmann's decision to forgo a complete orchestra in favour of a large string ensemble ( 26 violins, 10 violas, 8 cellos, 5 bass $^{27}$ ), enabled the mixing process to concentrate on the individual qualities of the instruments more closely. ${ }^{28}$ This intimacy, combined with sometimes slightly imperfect intonation, places what we hear into a more human scale; and what we hear brings us nearer to Marion. The music embodies what she is feeling, and we feel it with her. Her worry is now ours. Her journey is also ours, and her death will be an unbelievable shock.

Our anxiety is heightened when Marion sees her boss while driving, and the music here reverts to the opening music and its relentless rhythmic series of cells. Will he notice that she is not ill? Will he try to stop her? When she awakes at the roadside we are concerned about whether the policeman has been informed about her. At the used car lot, she looks at the newspaper to see if she's been reported. We wonder whether news has reached the owner. The first line he utters: "I'm in no mood for trouble", unsettles her (and us). The policeman watches her from across the road. All are suspicious of her. She begins to drive away but is stopped. Is the game up? No, she forgot to remove her suitcase from the older car. The opening music now returns us to her journey into the night and rain.

And then things relax for a while. At the motel, when Norman brings Marion her supper, the music reverts to opening tableaux - the hotel room's romanticism. We meet Norman and are seduced initially by his seeming innocence. Perhaps he could provide a more stable relationship for Marion. The music helps us infer that possibility. And then in the parlour, new music, as the subject of madness is discussed. This new music helps the audience begin to change their point of view from Marion to Norman. It consists of very high soft violin fragments accompanied by low string-bass gestures ${ }^{29}$. There is a pulse as well, which becomes more prominent after Marion leaves the room and Norman reverts to voyeur.

A change from bowed to plucked strings (arco to pizzicato) occurs at the point where a decision seems to have come to Norman, and the insistent rhythmic pattern becomes quite prominent as well. It then subsides somewhat and accompanies us into his house with him.

\footnotetext{
${ }^{26}$ Whether there was a conscious decision on Herrmann's part to signal the mood change through timbre is, in many respects, irrelevant. Suffice it to say that the change occurs congruently with a shift in her posture and seems to trigger her movement on the screen. My own view as a practitioner is that Herrmann would have been sensitive of the need for the music somehow to change at this point. ${ }^{27}$ according to The Musicians Guild of America's Studio Daily Report of 16-18 March, 1960. Normal practice would have been to divide the violins as 14 firsts and 12 seconds.

${ }^{28}$ For an account of how the music was likely to have been recorded, see Appendix 3, below.

${ }^{29}$ Herrmann refers to this cue as "madness" in his score. There may be some justification for hearing the music as comprising two distinct voices, kept well apart, then coming together, analogous to Norman/mother. (On the other hand, providing an underscore with very high and very low notes - and little between - would have been a seasoned film composer's way to keep out of the frequency range of the dialogue.)
} 
By now we have understood that Marion has decided to return the money. As she sits at the desk, the music again refers to the romanticism of Phoenix, and we are pleased that she is doing the right thing. She does some reckoning on a bit of paper. Perhaps they'll be lenient with her, as she only has stolen $\$ 700$, not the $\$ 40,000$. She then flushes the reckoning down the toilet. Then the shower, and we all know that scene ${ }^{30}$.

From the point that Marion's car disappears into the swamp, the job of the music as signifier of our emotional attachment with the MacGuffin comes to an end. From that point, music has little left to do. At first, it aids us in attaching to Norman, but in the main, from this point the music functions primarily as reprises (as in Arboghast's murder) or "business" cues, music to fill in spaces, provide trajectory, or any of the multitude roles it can assume in narrative films ${ }^{31}$.

Brown (1994), Sullivan (2007) and others have remarked on the absence of any diegetic music in the film. This, and the lack of any enhanced atmospheres, creates the information vacuum helpful for the audience to be immersed in the diegesis ${ }^{32}$. It can be noticed that much of the film's visual language borders on the mundane: the candlewick bedspread in Marion's modest flat; the barren landscape of the highway; the ten-apenny used car lot. In fact, the vernacular ordinariness of the visual world allows the viewer to enter into the extraordinary internal world of the main characters without distraction. In such a world, we are invited to involve ourselves in the emotions felt by the characters, and such involvement is made more vivid through the use of the music, long before the shower scene. This involvement is allowed more easily to happen through the spaces in the fabric of the film; openings, slowings down, pauses in action (e.g., when Marion is dressing, or when she is driving), which allow the audience space to enter her world, and the music the opportunity to create the anxiety with which to fill that space.

\section{On the Remake}

In 1998, Gus Van Sant directed a recreation of this film. Van Sant is one of his generation's most interesting and challenging film-makers. His Elephant (2003) and Last Days (2005) are remarkable films, not least for the use of music within a complex soundtrack $^{33}$. With Psycho his intention was to reassemble (rather than re-make) the film, using the same shots as in the original (he even uses one shot planned for the original, but cut from the final print) ${ }^{34}$. On the Extra Features segment of the DVD,

\footnotetext{
${ }^{30}$ There is an entire book on the subject of the shower scene, Philip Skerry's recent (2009) offering, Psycho in the Shower.

${ }^{31}$ For a list of cues after the murder, see Appendix 2, below.

${ }^{32}$ And of course, reflects mid 50s American tv drama practice.

${ }^{33}$ See Hildegard Westerkamp's article in The Soundtrack, 2.2, (2009) for a discussion of the gestation of this music.

${ }^{34}$ This is an overhead shot of Marion as she lies dead in the bath, the wounds very conspicuous on her back. Hitchcock excised the shot as being too explicit.
} 
Van Sant explains that he made the film partly because hardly anyone under 50 in the USA had seen the original, mostly put off because the Hitchcock version was in monochrome. ${ }^{35}$ He employed the original screen-writer, Joseph Stefano to update the dialogue. He also decided to re-record the original score (the task of minor rearrangements was given to Danny Elfman; the strings-only scoring was maintained). The music is here presented in stereo (as is the soundtrack for the rest of the film). There are many interesting aspects of the new film, and for those who have seen the original it allows for instructive comparisons.

For example, let's again focus on the "money" scene. Where the monochrome version was bland, here the colour is extravagant. We see a cacophony of hues; turquoise sheets, cherry red hat, green slip and bra. We hear Marion (Anne Heche) clearly, moving, tutting and thinking. We hear her vocalise her indecision about the money. There is also a constant exterior atmosphere which makes its presence felt through the open window; we hear birdsong (and even see a pigeon land in a bush outside). The music begins before we see the money, and it is much faster; where the original tempo was 108 beats per minute, the newer version is at 128 . This is no doubt due to the fact that the scene is now much shorter. The newer version has Marion leave her room after 1'23"; the original lasts almost 30" longer (ends at 1'50"). As a result, the music carries on into the scene where Marion is driving. The editor of the Van Sant film, Amy Duddleston, attests (in the Extra Features segment of the DVD) that she had to cut the film to play faster, as the original was so slow.

The effect of the faster cutting, the brisk tempo, and the smoother performance of the music (the players were after all familiar with the score; the original session musicians were charting new territory, and their unfamiliarity with the music added to the tension in the performance) nullifies to a great extent the effect that the music has in creating an anxious mood in the audience. And, with the faster tempo, the unsettling gaps between the notes are shorter, and filled with other sonic events. In the original film, the music carried the sound of the scene; here it is now one of the elements which creates a "filmic reality". Anxiety and ambivalence are strongly attenuated as a result. More importantly, the audience is no longer afforded the opportunity to "fill in" the gaps with meaning, nor the time so to do. One might consider whether the scene, as now constructed, really needed music at all.

The rest of the Van Sant film is in the same style. The decision to use Herrmann's music, which was composed for a film with few other competitive sonic elements, creates a dysfunctional melange within the acoustic elements of the film.

Of course, it is impossible for any of us familiar with the original objectively to gauge the effect of the newer version on an uninitiated viewer. Nevertheless, the trend toward

\footnotetext{
${ }^{35}$ It is an anecdotally supported truism that a sure-fire way to promote a film's box-office failure is to forgo colour.
} 
supplying too much information, and thereby placing the viewer at a distance from the emotional life on screen is quite common (although the exceptions are encouraging, for example, No Country for Old Men (2007), by Joel and Ethan Coen and The White Ribbon (2009) by Michael Haneke).

Little has been written about Psycho from a cognitive ${ }^{36}$ and emotional viewpoint, especially pertaining to its sound/music.. By examining a film's soundtrack for affect rather than solely through intention or as text, we may come closer to understanding how audiences make sense of film. Such an approach also gives us the opportunity to re-examine the role of the soundtrack in light of this understanding. A subsequent benefit would be the encouragement of the trend for music and sound to be considered as a single entity and to be involved in the production process from the script stage.

\footnotetext{
${ }^{36}$ It is necessary here to discriminate between several uses of the term "cognitive". In terms of psychological studies, the term refers to internal mental processes of thought. However, recent developments of Cognitive Theory in Film Studies, typified by works by Noël Carroll, Greg Smith and David Bordwell, have continued a debate about film theory's perceived orthodoxy in the areas of Psychoanalysis, Marxism and Barthesian semiotics. For the purposes of this article, however, the use of the word is intended as offering a polarity. As developed in my earlier taxonomy of the soundtrack (Deutsch, 2008), Cognitive stands at the opposite (but non exclusive) pole to Emotive. It implies a conscious reading of a film, what we think about what we see, as opposed to what we feel about what we are seeing.
} 
Appendix 1 Musical Examples

all extracts Copyright $\left(\mathcal{C} 1960\right.$ Ensign Music Corporation ${ }^{37}$

Opening Music:
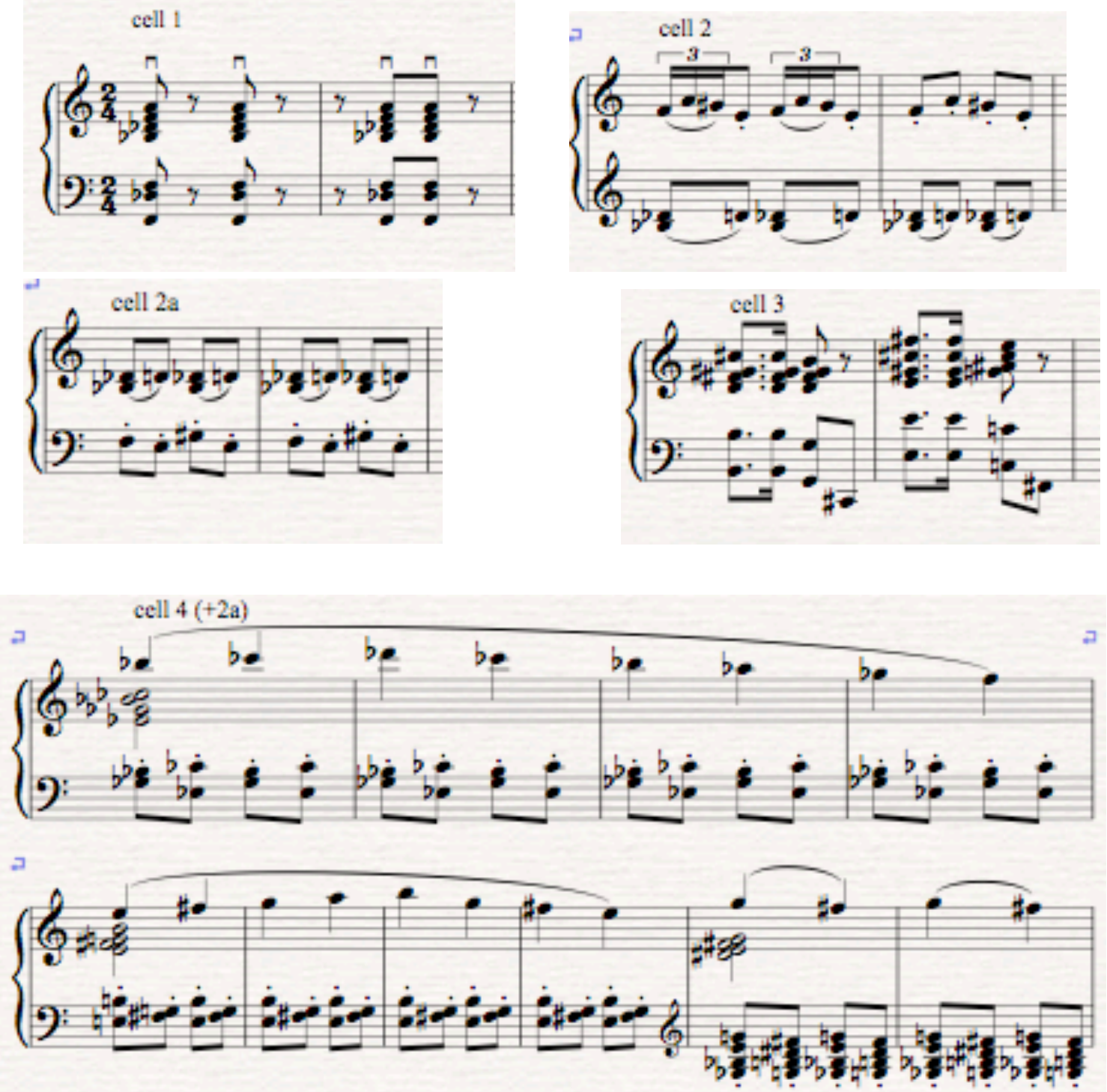

The pulse in the parlour

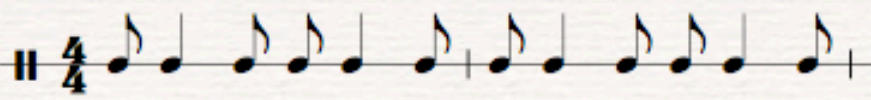

\footnotetext{
${ }^{37}$ These have been culled from hand-written transcriptions made by Roy Prendergast in his 1977 book (pp 138-142).
} 
The "money" (worry) music

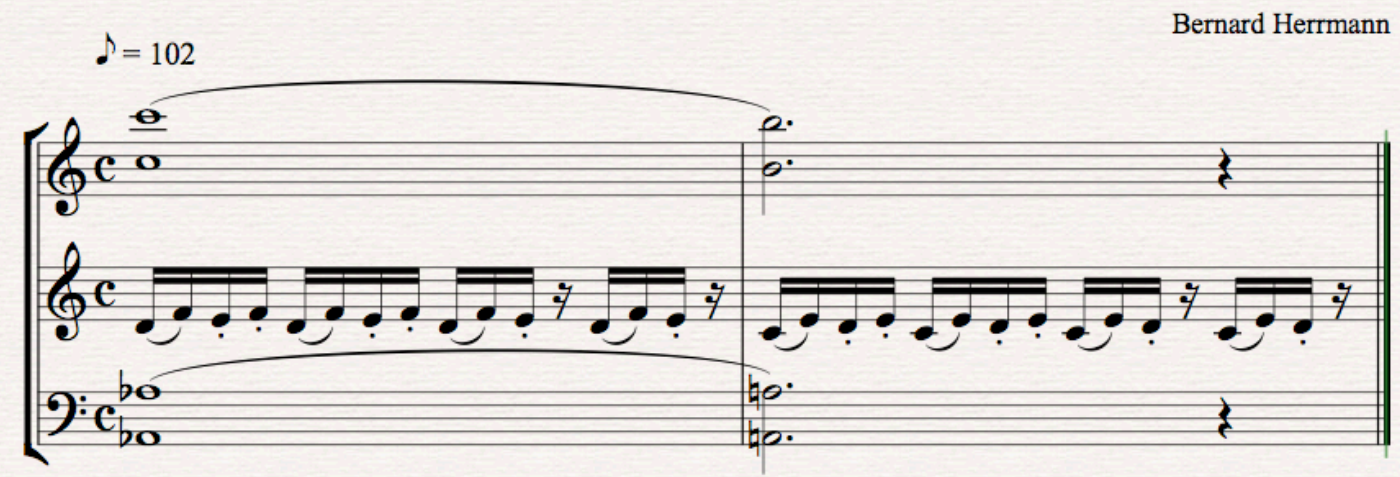

The viola line extended

Bernard Herrmann

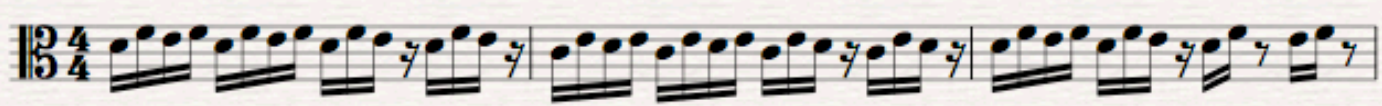

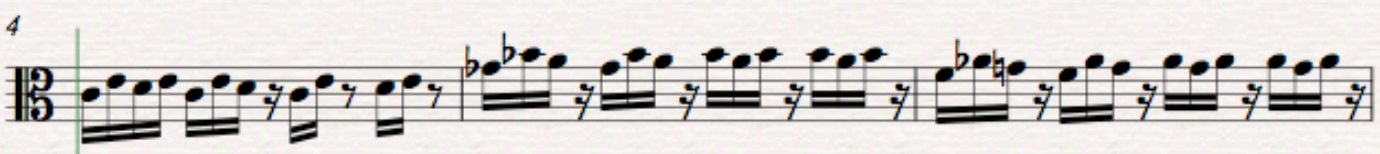

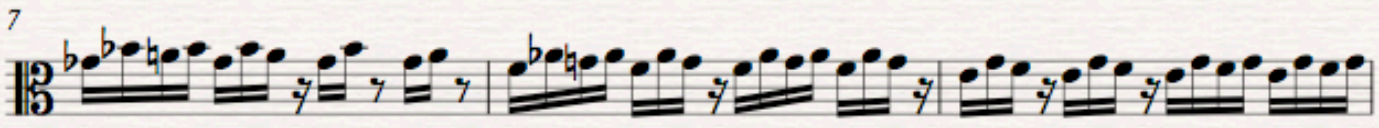

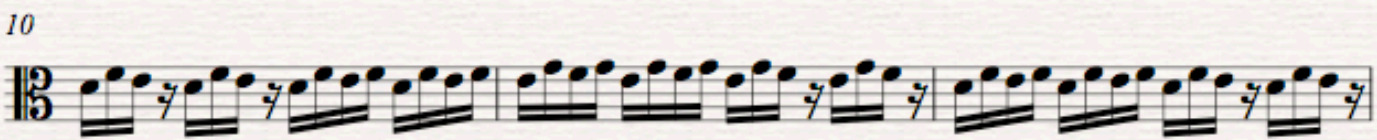


Appendix 2, music cues after murder:

timings approximate

\begin{tabular}{|c|c|c|}
\hline $47^{\prime}$ & Norman "finds" body & reprise 'madness' music \\
\hline 50 ' & cleaning & new music: trills and tremolos \\
\hline 52 ' & body into car & new music: octaves \\
\hline 53 & clearing away Marion's things & 'madness' music variation \\
\hline $1 \mathrm{hr} 01$ ' & Arbogast looking for Marion & light reprise of title music \\
\hline $1 \mathrm{hr} 07$ & Arbogast looks around & 'madness' music variation \\
\hline $1 \mathrm{hr} 08$ & Arbogast leaves & business: music, variation on previous cues \\
\hline $1 \mathrm{hr} 10$ & Arbogast returns & $\begin{array}{c}\text { madness' music variation when Arbogast } \\
\text { moves to house }\end{array}$ \\
\hline $1 \mathrm{hr} 13$ & Arbogast enters house & variation, higher notes, some harmonics \\
\hline $1 \mathrm{hr} 14$ ' & murder & shower music \\
\hline $1 \mathrm{hr} 15$ & $\begin{array}{l}\text { Lila alone in shop; Sam looks for } \\
\text { Arbogast at Motel }\end{array}$ & reprise of Norman's voyeur music \\
\hline $1 \mathrm{hr} 21{ }^{\prime}$ & $\begin{array}{c}\text { Bates goes into mother's room has a } \\
\text { conversation with her - to take her to fruit } \\
\text { cellar }\end{array}$ & 'madness' music variation \\
\hline $1 \mathrm{hr} 24$ & Sam and Lila arrive at motel & "business" music, legato strings, \\
\hline $1 \mathrm{hr} 28^{\prime}$ & Sam and Lila explore & "business" music, legato strings, \\
\hline $1 \mathrm{hr} 30^{\prime}$ & Lila goes to house & contrary motion stepwise music, suspense \\
\hline $1 \mathrm{hr} 32$ ' & Lila in Mrs Bates' room & legato strings with pulse \\
\hline $1 \mathrm{hr} 34^{\prime}$ & Lila in Norman's room & legato strings with pulse reprise \\
\hline $1 \mathrm{hr} 35$ & Norman rushes to house & new music, agitated strings, fast \\
\hline $1 \mathrm{hr} 36^{\prime}$ & in cellar, Norman attacks Lila & shower music + different ending \\
\hline $1 \mathrm{hr} 42$ & Mrs Bates speaks in N's mind & 'madness' music variation \\
\hline
\end{tabular}




\section{Shawn Murphy ${ }^{38}$ :}

What I can say would be regarding Universal Stage 10 and the method for scoring at Universal during that period.

More so than any other Hollywood Scoring Stage, Universal retained the "Standard Setup" in it's method. Even into the mid-late 1980's the Universal Stage had in place a standard set of chairs, risers, stands and microphones into which ALL sessions were configured. This came about of course due to the extremely busy recording schedules required by the Television industry, with three session days being more the norm than the exception. The standard setup would allow quick change over between ensembles, composers and productions. The recording mixer could just bring up the required faders and set his mix very quickly, with great efficiency in the recording process (quality notwithstanding).

At that time, and in fact throughout the thirties through the seventies and the demise of studio orchestras, all Scoring Stages retained some sort of standard setup.

In 1960, all music recordings would have been mastered on Magnetic Film, full coat, normally three track. There would have been a master copy and a "cutting copy". The master machine/copy would have been used for transfer reprints and archive. This method was used at virtually all studios during that period. The Magnetic Film recorders would normally have been RCA or Westrex and individually leveled to a flux level $6 \mathrm{~dB}$ below 3 percent harmonic distortion (considered to be effectively the same as optical clash). This level normally was around $320 \mathrm{nW} / \mathrm{m}$. There was no Dolby or other noise reduction, but the high reference level coupled with the quality of the magnetic film made for generally quiet and highquality recordings. I do not yet know the track layout for PSYCHO, but given the state of Universal Sound/Scoring at that time, I would guess that a three track, multi mono format was used. It may have been something like High Strings/Low Strings/String Effects, or more likely, a single track mono mix. There would have been no multitrack on magnetic tape or film. (Mixing desks at that time had no multitrack capabilities, there were no electronic synchronizers, and the widest non-sprocketed recorders were 3-track, the widest sprocketed was 6-track).

As to the balancing and monitoring, I would suppose it was done entirely by ear in the studio. If there were headphones used, it would have been only for synchronization/click tracks. Given Bernard Herrmann's musicianship, I would think there may have been no cans ${ }^{39}$ at all and all cueing was by marked picture and/or clock timings.

e-mail 03/03/10

\footnotetext{
${ }^{38}$ Shawn Murphy is one of the leading music mixers in Hollywood, whose credits include: 2012 (2009); Ice Age (2009); The Curious Case of Benjamin Button (2008); Charlie Wilson's War (2007); as well as over 300 others, starting with the remix of the music for Fantasia (1940/1982). His full credits can be found at: http://www.imdb.com/name/nm0004156/.

${ }^{39}$ i.e., headphones
} 
Sources:

Baker, R, Emotional Processing, 2007, Lion Books

Brown, R, Overtones and Undertones: Reading Film Music, 1994, University of

California Press

Deutsch, S. "Putting Music in its Place" in The Soundtrack, Volume 1 number 1, 2008, Intellect Press

Deutsch, S. "A Concise History of Western Music for Film-makers" in The Soundtrack, Volume 2 number 1, 2009, Intellect Press

Farah, M, Chepenik, L and Cornew, L, "The Influence of Sad Mood on Cognition" in

Emotion, 2007, Vol. 7 No 4, 802-811, American Psychological Association, USA

Hitchcock, A, Psycho 1960. (DVD, 2005), Universal Pictures, USA

Ives, C. The Unanswered Question, 1906, Schirmer, NY

Levitin, D, This is Your Brain on Music, 2006, Plume (Penguin), NY

Marschall, R, The Golden Age of Television. 1987, Bison Books, NY

Mithen, S, The Singing Neanderthals, 2005, Weidenfeld \& Nicholson, NY

Prendergast, R, Film Music: A Neglected Art. 1977, Penguin, NY

Rebello, S, Alfred Hitchcock \& the Making of "Psycho". 1990 Mandarin, UK

Skerry, P. Psycho in the Shower. 2009, Continuum Books, NY

Stravinsky, Petrushka, 1909, Boosey \& Hawkes, UK

Sullivan, J, Hitchcock's Music, Yale University Press, USA 2007

Thayer, R, The Origin of Everyday Moods, 1996, Oxford University Press

Thayer, R, The Biopsychology of Mood and Arousal, 1989, Oxford University Press

Truffaut, F, Hitchcock, 1978 Paladin, UK

Vitouch, O., "When Your Ear Sets the Stage: Musical Context Effects in Film

Perception" in Psychology of Music, 2001, 29, 70-83, USA

Weis, E., The Silent Scream. 1982 Associated University Presses, London

Van Sant, G, Psycho, 1998 Universal Pictures, US 